\title{
Aesthetics for mine closure
}

\author{
G. McKenna BGC Engineering Inc., Canada \\ E. Scordo BGC Engineering Inc., Canada \\ D. Shuttleworth BGC Engineering Inc., Canada
}

J. Straker Integral Ecology Group, Canada

B. Purdy Alberta Environment, Canada

J. Buchko Phillips Farevaag Smallenberg, Canada

\begin{abstract}
There have been several historic attempts to quantify the aesthetics of natural landscapes, and many mines around the world are building reclaimed landscapes with a focus on visual appeal and/or natural appearance. There have been arguments made that form and function are closely linked, and hence mining landscapes should be fashioned to look natural; to look as though they have been the product of geomorphic change similar to that experienced over thousands or millions of years by the surrounding natural landscape, while some argue that aesthetic reclamation should be done for purely aesthetic purposes. Still others argue that preserving some of the historic / industrial features of a mining landscape is an important way of connecting humans to the land and its history, and hence preservation of historical resources can be an important element of mine reclamation.
\end{abstract}

Our paper explores the interaction of these various concepts, ideas, and philosophies, and presents examples of bringing aesthetic considerations into landform design for mine closure. It offers qualitative and semiquantitative measures to design, construct, and evaluate aesthetics and natural appearance in mine closure, and offers a scorecard that may form a starting point for constructive dialogue.

\section{$1 \quad$ Introduction and background}

Aesthetic considerations are important for many mine closure projects (McKenna, 2002). Reasons for adoption of aesthetics / natural appearance goals are explored in this paper along with some definitions and tools to aid mining companies, regulators, and stakeholders.

It is worth considering the historical context for mine reclamation. Mine reclamation is a relatively new field, with beginnings in the 1960s and 1970s (US Department of the Interior, 1967). At that time, for most mines the standard of practice was to simply abandon the mines unreclaimed when the ore ran out (Cummins and Given, 1973). The early days of reclamation leaned heavily on widespread, but generally small-scale civil engineering experience focussed on geotechnical stability by re-sloping dumps and erosional stability by using planar slopes and agronomic grasses to encourage sheetflow runoff. The resulting landforms were usually artificial looking and had low topographic and ecological diversity, but were a marked improvement over previous practices. Closure planning, including the adoption of specific post-mining land uses and stated reclamation goals started in earnest two decades later (Ontario Ministry of Northern Development and Mines, 1996). As mines become larger, and the reclamation and closure goals more onerous, traditional reclamation methods often do not allow mines and their regulators to sign-off on the reclamation as complete, largely due to uncertainty in future reclaimed landscape performance relative to expectations (McKenna, 2002). Currently, the practice of landform design applied to mining landforms (such as dumps, pits, creeks, and dams) integrated within mining and natural landscapes to meet well-defined goals, is emerging in many countries in an attempt to create more sustainable mining landscapes.

In particular, designing for aesthetics and natural appearance is an emerging technology with three drivers a desire to provide good landscape performance by mimicking natural appearance (Keys et al., 1995; Schor and Gray, 1995), regulatory requirements (e.g. Alberta's Environmental Protection and Enhancement Act 
(EPEA) Approvals for Canadian oil sands projects), and corporate goals (McKenna, 2009). More recently, the use of landscape architecture (including the creation of aesthetic forms) for landform design is becoming a driver at some mine sites (Pearman, 2009; Buchko and Hitch, 2010). Landscape architects aim to create an integrated design approach, looking at a multitude of systems (both cultural and scientific) and a range of scales. The merging of these various systems and scales results in a dynamic solution that reflects the character, functions and requirements of the landscape.

A number of concerns about including aesthetics as a design consideration have been raised. These include concerns about the subjective nature of both aesthetics and natural appearance, concern that aesthetic considerations may displace operational safety, cost, and geotechnical considerations, concern that aesthetic or historic preservation may come at the expense of other land use goals (such as wildlife habitat, commercial forestry, and agricultural uses), and a general concern regarding know-how, cost, and other uncertainty related to the adoption of new technology. Clearly risks, performance, and cost need to be carefully weighed, and tradeoffs in design are inevitable. Ideally, as described below, designing for natural appearance should enhance long-term landscape performance and reduce liability. Similarly, one can use smart design strategies and functional solutions, which in turn create a positive aesthetic.

When we consider the aesthetics of a mining landform, the visual appearance usually dominates the discussion. Moreover, whether the landform is seen to have a natural appearance usually dominates the discussion. Natural appearance can be defined as the property of a mining landform to be visually similar to that of landforms in the region as viewed from the ground by people involved in proposed end land uses, and at a stage when the vegetation is mature (topographic appearance should be evaluated at the design and regrading stages). Elements of natural appearance may include topographic form and native vegetation occurring in patterns similar to those of surrounding natural areas, and creeks and rivers with form and function similar to those of adjacent undisturbed areas. One may also wish to design reclaimed landscapes as a representation and symbol of the sensibility of the culture, embracing elements such as agricultural use, open pit mines, and windfarms as part of the cultural landscape.

This paper describes some of the authors' and others' experiences in incorporating aesthetics in mine reclamation and closure, and provides some of the tools and know-how used. As this is an emerging technology, there is considerable room for sharing of experience.

Much of the work presented in this paper is an extension of a conference paper by McKenna, (2009) and recent unpublished work on oil sands landform design supported by Alberta Environment and the Cumulative Effects Management Association (CEMA).

\subsection{State of practice}

As described previously, most mine reclamation is currently focussed on creating landscapes that support wildlife habitat, forestry, or agricultural uses with a focus on human safety, geotechnical and erosional stability, and good vegetative cover (McKenna, 2002). Aesthetic considerations are becoming more common, as indicated in Table 1. 
Table 1 Examples of mines incorporating aesthetics in mine reclamation

\begin{tabular}{ll}
\hline Location & Examples of Elements Employed \\
\hline * Anaheim residential, CA & Landform grading \\
$*$ BHP Billiton Potash, SK & Landform grading for soil stockpiles, sight barriers \\
* Cheviot Coal, AB & Landform grading, slope roughening, meandering creeks \\
Cardinal River Coal, AB & Landform grading, snags, rockpiles, littoral zone, slope \\
& roughening, ridgelines, lakes, meandering creeks \\
Falconbridge Copper, ON & Preservation of historic areas \\
Faro Lead/Zinc, YT & Roughening \\
Highland Valley Copper, BC & Roughening, meandering creeks \\
Island Copper, BC & Sculptured shorelines, snags \\
$*$ Line Creek Coal, BC & Dump roughing, sculpted coal waste piles \\
$*$ MiBrag Coal, Germany & Sculpted shorelines for pit lakes \\
Molycorp Molybdenum, NM & Angle of repose planting \\
$*$ Premier Coal , WA, Australia & Sculpted beaches, natural revegetation planting \\
$*$ Price Coal, UT & Slope roughening, diagonal swales \\
Pueblo Viejo, & Landform grading, tailored planting \\
Dominican Republic & \\
SF Phosphate, UT & Slash \\
$*$ Suncor Oil Sands, AB & Landform grading, ridge mounds, irregularly shaped wetlands, \\
$*$ Syncrude Oil Sands, AB & native vegetation, snags and rockpiles, islands \\
* TransAlta Highvale Coal, AB & Landform grading, roughening, ridge mounds, rockpiles, native \\
\hline NOTE:*indicates sites where the majority of new landforms are designed to have natural appearance Table adapted from McKenna (2009) & \\
\hline & vegetation
\end{tabular}

NOTE: * indicates sites where the majority of new landforms are designed to have natural appearance. Table adapted from McKenna (2009).

While such techniques are becoming more common, many landforms proposed and under construction still have elements of artificial appearance.

\subsection{Desire for natural appearance}

McKenna (2009) lists the key reasons for designing for natural appearance to:

- Meeting promises made to stakeholders.

- Meeting regulatory requirements.

- Public relations value.

- Creating diversity in the landscape which in turn promotes resiliency - a useful element of landscape performance (Holling, 1973).

- Following the "form follows function" principle - a landscape that is designed to exhibit similar landscape performance (function) as the natural environment should look natural (form).

It is worth noting that the natural appearance of undisturbed landscapes is the product of complex interactions between the bedrock and surficial deposits with historic effects of groundwater, surface water, climatic events, soil-forming processes, animal effects, and in many cases, glacial and other catastrophic 
geological processes. These geological processes have been working at pre-mining landscapes over millions of years and continue today.

These natural processes that include mass movement and erosion are phenomena that would typically be classed as geotechnical failures or accelerated erosion if they occurred on reclaimed landscapes. The current regulatory and engineering paradigm is to design against such unwanted events. There is some inherent tension in trying to create landforms with an appearance caused by processes that are usually considered undesirable in the reclamation environment. Operators are directed to try to recreate the products of these processes by mechanical means, while ensuring that the processes themselves do not occur (or occur very slowly) on reclaimed landforms. Designing for aesthetics requires recognition of this tension and context.

\subsection{Form and function}

The notion of "form and function" is defined by landscape ecology function (Forman and Godron, 1986), in which "form" refers to particular attributes, qualities or components of the natural landscape. Landscape forms have evolved over time and represent morphologies that are both shaped by and shape various natural functions, for example, convex upward slopes formed under the influence of erosion, braided rivers transporting sediments across the floodplain. In landscape ecology, "function" (or process) is considered the interaction or flow of energy, material and species among the components of an ecosystem. Form and function are fundamental characteristics of the landscape. Designers often seek to avoid form for form sake the form must fulfil its intended function in order to truly be worthwhile.

Mining landforms, and the creeks and valleys that connect them, should be designed to have a form that fits their function. Most notably, swales that have the ability to shed surface water with minimal erosion including, (1) steeper slopes where the fluxes of surface water during snowmelt and storms is small, (2) flatter slopes where tractive forces from runoff are higher, or (3) slopes heavily armoured with alluvial material (boulders, cobbles, gravel) where the water has higher erosion potential and tends to accumulate. Design of slopes with forms to meet this function can be done analytically (to a certain degree) and perhaps more reliably, with the application or regional natural analogues.

\subsection{Natural analogues}

In the oil sands region of Alberta, replicating the form and function of natural analogues is promoted as a design framework (Keys et al., 1995). Use of natural analogues as a strategy provides recognition that designers cannot fully understand the intricacies and interactions of various landform elements, e.g. substrate, reclamation material, flora and fauna, climate. Replication of natural analogues is an attempt to mimic their form and function on the reclaimed landscape.

For example, closure drainage systems are patterned after natural analogues to achieve characteristics similar to pre-development drainage systems in terms of stability, robustness and self-healing processes. A geomorphic approach to channel design is common in the oil sands, and may include designing watercourses with reference to characteristic natural geomorphology, plan form, spacing, slopes, channel dimensions, bed and bank material, soil conditions and vegetation (form) to adequately convey surface runoff (function) and, therefore, account for major landform processes such as soil and substrate erosion. Beyond design of water courses, drainage density, and elements of catena, other natural elements that are and potentially can be applied to reclaimed landscapes include slope geometry, topographic roughness, ecosites and ecosite phases, soil profiles and thicknesses, and characteristics of wildlife movement corridors.

\subsection{Diversity}

Although the concept of enhancing natural appearance is a relatively new landscape performance objective, there is a growing sense of its importance in the development of sustainable ecosystems. This shift in the design paradigm is driven in part by knowledge that climate, topographic relief, hydrology and soils work in concert to drive ecosystem formation and maintenance. A pillar of sustainable ecosystems is diversity. Designing for diversity in turn promotes ecosystem resiliency to disturbance and natural forces such as fire, erosion, insect damage, extreme flooding and drought, resulting in increased landscape performance (Holling, 1973). This includes designing and constructing landforms to be capable over time of achieving 
and maintaining levels of productivity and diversity of plants and animals comparable to the natural terrestrial and aquatic ecosystems of the region.

Landform design can enhance diversity in terms of topography, surface water drainage, substrates, soils and vegetation, including:

- Topography: ridges, swales, hummocks (steepness, aspect, convex, concave).

- Surface water: shorelines, riparian zones, channel sizes, channel morphology, meandering versus straight channels.

- Groundwater diversity: recharge and discharge zones, seepage areas, soil moisture gradients.

- Substrates: textural classes, materials characteristics, substrate topography.

- Soils: thickness and texture, organic content, layering, machine placement, compaction.

- Vegetation: planting prescriptions and ecosystem succession, patch size and shape.

Topographic diversity is perhaps the simplest type of diversity that can be built into the landscape.

\subsection{A question of scale}

Discussion of natural appearance of mining landforms requires an appreciation of scale. Table 2 provides a definition based on spatial extent. This paper deals with landform design, with a focus at meso and macro scales. Design for the broader landscape and regional scales will be left to a later paper.

Table 2 Scales for aesthetic designs of landforms

\begin{tabular}{|c|c|c|c|c|}
\hline Scale & & $\begin{array}{l}\text { Spatial } \\
\text { Extent }(m)\end{array}$ & Description & Application \\
\hline \multirow{3}{*}{ Landform } & Micro & $1-10$ & $\begin{array}{l}\text { Result of reclamation soil management and } \\
\text { differential settlement. Not the direct result of } \\
\text { an engineered design, but can be field fit } \\
\text { (e.g. surface roughness). }\end{array}$ & \multirow{3}{*}{$\begin{array}{l}\text { Natural } \\
\text { appearance }\end{array}$} \\
\hline & Meso & $10-100+$ & $\begin{array}{l}\text { Surface drainage features (e.g. swales) and } \\
\text { hummocks that require an engineered design. }\end{array}$ & \\
\hline & Macro & $100-1000+$ & $\begin{array}{l}\text { Equivalent to landform scale engineered } \\
\text { design; includes the footprint design and may } \\
\text { include larger surface water drainage features. }\end{array}$ & \\
\hline Landscape & & $10,000+$ & $\begin{array}{l}\text { Equivalent to lease scale. Landforms must be } \\
\text { integrated by engineered design. }\end{array}$ & \multirow[b]{2}{*}{$\begin{array}{l}\text { Landform } \\
\text { integration }\end{array}$} \\
\hline Regional & & $100,000+$ & $\begin{array}{l}\text { Multiple, adjacent landscapes/leases. } \\
\text { Landforms must integrate by design } \\
\text { (e.g. surface water drainage). }\end{array}$ & \\
\hline
\end{tabular}

\subsection{Quantifying aesthetics and natural appearance}

McKenna (2009) provides an overview of some of the historic attempts to quantify scenic beauty, and perhaps by extension aesthetics and natural appearance. These approaches have largely become historical footnotes and are not broadly employed. The following section provides direction for qualitative and semi quantitative approaches. 


\section{How to design for aesthetics / natural appearance}

This section provides hand-on tools for design of aesthetics / natural appearance. It provides a mine planning framework for design, and looks at looks at qualitative and quantitative tools and a scorecard.

\subsection{Stages of planning and design}

Landform design is not a single activity at a given time and place. Because landform design begins at the mine exploration / permitting process and ends after closure, the design process typically spans decades, even centuries (with analogies to urban design (Kostof, 1991). Table 3 provides a guide to the level of detail at the various mine planning stages.

Table 3 Integration and natural appearance opportunities by stages of planning and construction

\begin{tabular}{|c|c|c|}
\hline Stage & Typical Level of Detail & Opportunity/Milestone \\
\hline Regional planning & $\begin{array}{l}\text { Most general of plans, focus on lease } \\
\text { boundaries and regional reclamation } \\
\text { objectives }\end{array}$ & $\begin{array}{l}\text { Institute this step in the process } \\
\text { on a period basis }\end{array}$ \\
\hline Lease closure planning & $\begin{array}{l}\text { Conceptual designs for all landforms } \\
\text { and drainage, explicit documentation } \\
\text { of goals and schedules }\end{array}$ & Joint assessment of plans \\
\hline $\begin{array}{l}\text { Permit-level landform } \\
\text { design }\end{array}$ & $\begin{array}{l}\text { Technical landform design for all } \\
\text { aspects of landform }\end{array}$ & Joint assessment of designs \\
\hline Construction drawings & $\begin{array}{l}\text { Specific details, contours, survey, } \\
\text { sequencing }\end{array}$ & Generally internal to operators \\
\hline Construction & $\begin{array}{l}\text { Annual topographic as-builts, visual } \\
\text { inspections }\end{array}$ & $\begin{array}{l}\text { Monthly field inspections, } \\
\text { annual comparison of as-builts to } \\
\text { plans for critical areas }\end{array}$ \\
\hline End of construction & $\begin{array}{l}\text { Topographic as-built, visual } \\
\text { inspections }\end{array}$ & Examination of regrading plans \\
\hline End of regrading & $\begin{array}{l}\text { Topographic as-built, visual } \\
\text { inspections }\end{array}$ & $\begin{array}{l}\text { Field inspection; comparison of } \\
\text { as-builts to plans for critical } \\
\text { areas; examination of } \\
\text { reclamation material placement } \\
\text { plans and revegetation }\end{array}$ \\
\hline $\begin{array}{l}\text { End of reclamation material } \\
\text { placement }\end{array}$ & $\begin{array}{l}\text { Topographic as-built, soil thickness } \\
\text { documentation, visual inspections }\end{array}$ & $\begin{array}{l}\text { Examination of revegetation } \\
\text { plans }\end{array}$ \\
\hline End of revegetation & Planting report & Documentation of compliance \\
\hline $\begin{array}{l}\text { Field inquiry for } \\
\text { reclamation certification }\end{array}$ & $\begin{array}{l}\text { Detailed application for reclamation } \\
\text { certification }\end{array}$ & $\begin{array}{l}\text { Documentation of compliance } \\
\text { and review of field performance, } \\
\text { including documentation of } \\
\text { above milestones }\end{array}$ \\
\hline
\end{tabular}

\subsection{A qualitative approach}

A qualitative design-approve-build-inspect approach has been used effectively with respect to regulation of architecture of major buildings in cities - a proponent submits an artist's/architect's rendition of a proposed design with all architectural elements shown, and with the building set in the surrounding neighbourhood. This rendition is reviewed, potentially adjusted, and constructed when approved. If the final building differs 
from the approved design, e.g. the proposed awnings or lighting were not installed, the occupancy permit is withheld until the city planners are satisfied that the building has been constructed as proposed.

While this approach to design and approval has potential for widespread use in the mining industry for creation of mining landforms with natural appearance, to date there has not been the process and/or rigour to ensure that what is proposed is actually constructed. Indeed, mining landforms are often constructed over years or decades, going through a multitude of small and large design changes, and often look little like their original designs. Due to the nature of mine planning and the magnitude of mine landform construction, it is typically not practical or even possible to conduct any but the smallest retrofitsor adjustments on a completed mine landform. Thus a key element of using a design-approve-build-inspect approach for mine landforms would be to identify and address deviations from planned design as they occur (see Table 3), rather than simply at landform completion, i.e. through a milestone-based inspection/adjustment/approval system.

One of the simplest and most effective qualitative approaches to creating natural appearance is to use revegetated mining landforms using native vegetation from surrounding natural areas and planting in patterns that mimic natural ones. Furthermore, there is an opportunity to continue topographic and vegetation patterns (from adjacent natural swales, plateaus, and ridges) by integrating the topographic and vegetative patterns on the mining landforms. For example, if a rockdump is built above a natural drainage, one could continue the form and vegetation patterns from the natural drainage up through a constructed swale on the rockdump.

McKenna (2009) provides a cafeteria-style list of landform design elements that includes nearly two dozen elements/strategies for creating landforms with natural appearance. These elements have been used with success at several oil sands mines.

\subsection{Semi-quantitative approaches}

Four approaches are suggested in the following sections.

\subsubsection{Simple topography and range of natural variability}

This approach relies upon an inventory and statistical examination of typical geometric properties of landform in the region. Such an inventory was prepared by MacMillan et al. (2006) for the oil sands region. The natural range of geometries of regional landforms can be tabularised - in the case of the oil sands work, characteristics such as landform length, width, slope length, slope height, slope angle, and typical watershed size. Mining landforms can be designed to be within these natural ranges. As both mining and natural landforms are complex, there is considerable judgement that needs to be employed in using this strategy. In the case of the oil sands, traditionally designed mining landforms already fit within the natural range of variability.

\subsubsection{Landform topographic sinuosity}

In the same way that geomorphologists determine the sinuosity of a creek or river as the ratio of the length of the flow path versus the straight line distance, the topographic sinuosity of a constructed landform can be measured by comparing the length of a contour line (over a given scale) versus the straight line distance. For example, a conventionally constructed rockpile with a planar slope would have a topographic sinuosity of close to 1. Ratios of 1.2 to 1.5 are indicative of a series of deeply incised swales / watershed on a rockpile face and can be considered to have high degree of topographic diversity. CAD or GIS tools can be used to automate measurements. Use of such tools is still under development and we are presently experimenting with different definitions and scales.

\subsubsection{Drainage density}

The drainage density (defined as the ratio of the total stream length to the watershed area) on a landform slope or plateau is a good measure of topographic diversity and one can argue that this drainage density of mining landforms should be designed to be similar to that of natural landforms in the region. It is easily measured for natural watersheds, design watersheds, and as-built mining landforms. 


\subsubsection{Topographic roughness index}

Topographic roughness can be defined as the surface area of a landform to the plan view area and is the three-dimensional analogue to a more two-dimensional topographic sinuosity. "Rough" landforms have greater topographic diversity and typically have greater natural appearance. The roughness calculation can also be automated.

\subsection{Scoring natural appearance}

Table 4 provides a table for scoring natural appearance under consideration for the oil sands region of Alberta.

Table 4 Scoring natural appearance

\begin{tabular}{|c|c|c|c|}
\hline Item & Low & Medium & High \\
\hline \multirow[t]{5}{*}{ Topography } & $\begin{array}{l}\text { Planar } \\
\text { Near lack of swales }\end{array}$ & $\begin{array}{l}\text { Combination of planar slopes } \\
\text { and engineered channels }\end{array}$ & $\begin{array}{l}\text { No planar slopes, lots of } \\
\text { ridges and swales }\end{array}$ \\
\hline & $\begin{array}{l}\text { Topographic sinuosity of } \\
1.0 \text { to } 1.05\end{array}$ & $\begin{array}{l}\text { Topographic sinuosity of } 1.05 \\
\text { to } 1.2\end{array}$ & $\begin{array}{l}\text { Landform design (pyramidal, } \\
\text { diagonal ridges) }\end{array}$ \\
\hline & Ridgeline roughness $<1.1$ & Ridgeline roughness 1.1 to & Mounds \\
\hline & & 1.15 & $\begin{array}{l}\text { Topographic sinuosity may be } \\
>1.2\end{array}$ \\
\hline & & & Ridgeline roughness $>1.15$ \\
\hline \multirow{2}{*}{$\begin{array}{l}\text { Micro- } \\
\text { topography }\end{array}$} & Mostly smooth & Roughness elements, but & Frequent small mounds over \\
\hline & Few mounds & localised or infrequent & large areas \\
\hline $\begin{array}{l}\text { Large-scale } \\
\text { roughness }\end{array}$ & Low variability & Moderate variability & High variability \\
\hline \multirow{7}{*}{$\begin{array}{l}\text { Surface } \\
\text { drainage }\end{array}$} & Poor surface drainage & Linear drainage ditches for & Channels constructed in \\
\hline & No defined channels & drainage & regime (geomorphic \\
\hline & Low drainage density & Channels heavily armoured & approach) \\
\hline & Straight channels & Low drainage density to slope & Meandering creeks \\
\hline & & ratio & Drainage density fits within \\
\hline & & Some meander to channels & range of natural variability \\
\hline & & & $\begin{array}{l}\text { Channels designed } \\
\text { geomorphically }\end{array}$ \\
\hline Soil placement & $\begin{array}{l}\text { Uniform soil thicknesses } \\
\text { based on approval } \\
\text { conditions }\end{array}$ & $\begin{array}{l}\text { Variable soil thicknesses and } \\
\text { layering for diversity, } \\
\text { adaptation to local conditions }\end{array}$ & $\begin{array}{l}\text { Designs using the catena } \\
\text { approach with a focus on } \\
\text { transition zones }\end{array}$ \\
\hline \multirow[t]{4}{*}{ Revegetation } & Uniform vegetation & Blocky patches with some & Vegetation follows guidelines \\
\hline & Geometric (straight) & diversity & for topography, i.e. sinuous \\
\hline & $\begin{array}{l}\text { boundaries between } \\
\text { vegetation types }\end{array}$ & $\begin{array}{l}\text { Trees and shrubs not planted } \\
\text { in straight lines }\end{array}$ & $\begin{array}{l}\text { boundaries between } \\
\text { vegetation types }\end{array}$ \\
\hline & Non-native vegetation & Native vegetation & $\begin{array}{l}\text { Vegetation corresponds to } \\
\text { topographic variation, } \\
\text { appropriate for } \\
\text { substrate/cover moisture } \\
\text { conditions, i.e. wetter site- } \\
\text { type vegetation in swales, etc. }\end{array}$ \\
\hline Infrastructure & $\begin{array}{l}\text { Conspicuous roads, } \\
\text { buildings, powerlines, } \\
\text { pipelines, laydown areas }\end{array}$ & $\begin{array}{l}\text { Reduced infrastructure, good } \\
\text { screening and paint schemes, } \\
\text { narrow winding access roads }\end{array}$ & Lack of infrastructure \\
\hline
\end{tabular}


Russell et al. (2010) provide details of the design of Suncor Pond 1 reclamation, a 220 ha tailings plateau designed to score medium to high in the elements in Table 4.

There are numerous other tools that can be employed and are under development. The operational know-how to build in topographic sinuosity, drainage density and topographic roughness are available from Schor and Gray (1995) and have been applied to mining landforms over the past two decades. There remains, however, room for design and operational efficiency as well as wider adoption.

The use of such tools by mines, regulators, and stakeholders can be powerful, but is based on these groups having shared goals and a willingness to work together. In particular, the measures can be "gamed" by individual parties; for example, contours composed of many short straight lines will provide high sinuosity but perhaps low natural appearance (and perhaps high aesthetics for those who like linear geometric patterns). A willingness to work together towards common outcomes is indicated if positive outcomes are sought.

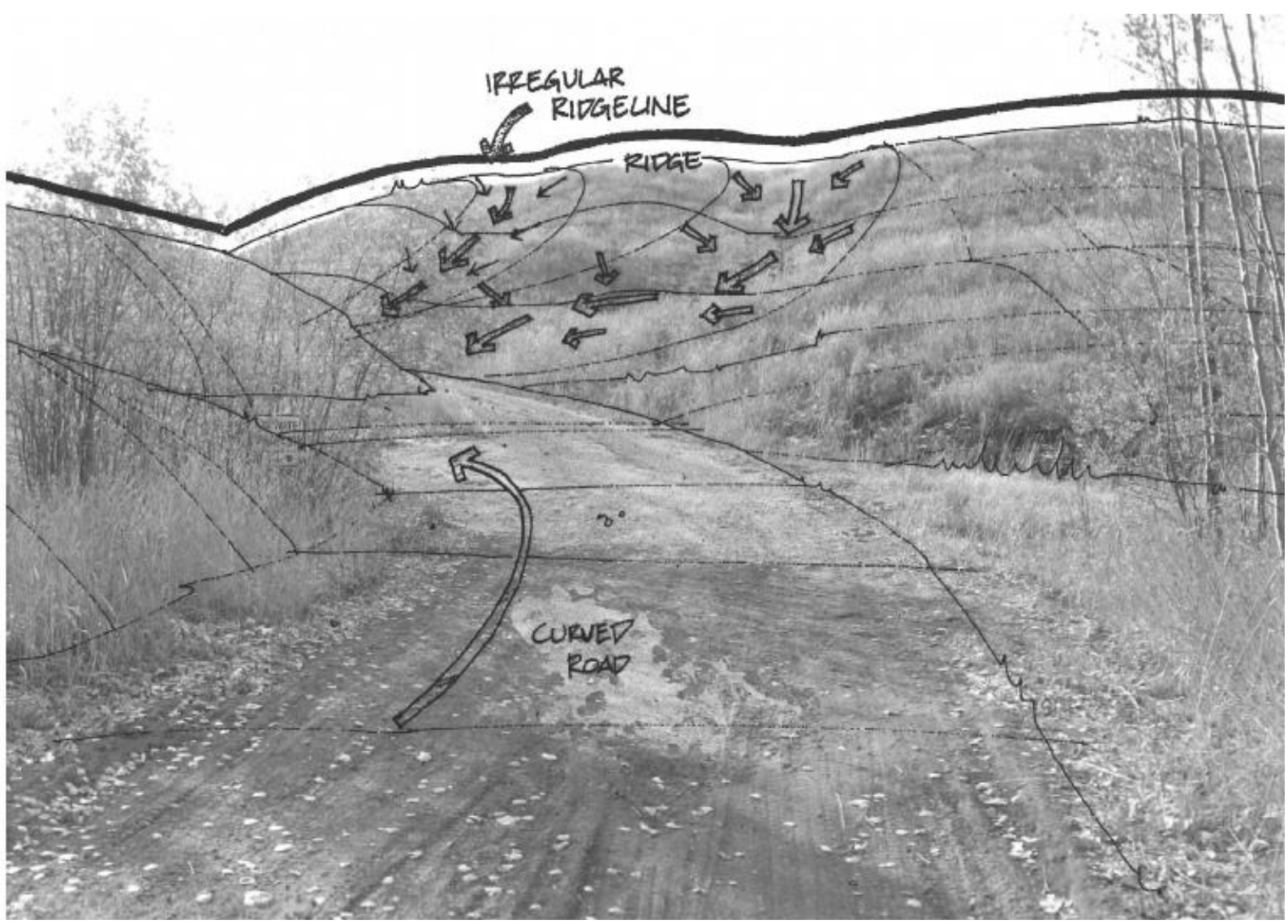

Figure 1 TransAlta sight and sound berm

Figure 1 provides a visual example of a positive outcome in design for natural appearance. The TransAlta Site and Sound Berm at the Highvale Coal Mine west of Edmonton, Alberta were constructed by a dragline placing spoils from the initial boxcut (Cam Bateman, personal communication). The berm was re-graded with topographic elements and tailored planting to provide a pleasing natural appearance that fits the natural region and was largely "field fit" by capable operators under the direction of the mine reclamation specialist.

\section{$3 \quad$ Next steps}

Designing and constructing mining landforms and landscapes with aesthetics and natural appearance in mind is becoming more common. One of the greatest impediments is the lack of knowledge of successes (and failures) at other mine sites and the techniques employed. There is an opportunity for publication of more case histories and the development of design and measurement tools ultimately aimed at providing a sound basis for including aesthetics in landform design and construction at more locations. Inclusion of landscape 
architects ("placemakers") in the landform design team will provide fertile ground to incorporating aesthetics (and other human goals) for the design of reclaimed landscapes.

\section{Acknowledgements}

Alberta Environment, Cumulative Effects Management Association, Suncor Energy Inc, Syncrude Canada Ltd, and Total E\&P are thanked for their support of the research, field trials, and commercial application of the work presented in this paper.

\section{References}

Buchko, J. and Hitch, M. (2010) Designing the Reclaimed Landscape - Integrating Landscape Architecture into the Mining Process, Proceedings Fifth International Conference on Mine Closure (Mine Closure 2010), A.B. Fourie, M. Tibbett and J. Wiertz (eds), 23-26 November 2010, Viña del Mar, Chile, Australian Centre for Geomechanics, Perth, pp. 251-260.

Cummins, A.B. and Given, I.A. (1973) SME mining engineering handbook, Society of Mining Engineers of the American Institute of Mining Metallurgical and Petroleum Engineers Inc, 2 volumes.

Forman, R.T.T. and Godron, M. (1986) Landscape ecology, New York: Wiley, 619 p.

Holling, C. (1973) Resilience and stability of ecological systems, Annual Review of Ecology and Systematics 4, pp. $1-23$.

Keys, M.J., McKenna, G., Sawatsky, L. and Van Meer, T. (1995) Natural analogs for sustainable reclamation landscape design at Syncrude, In: COGEMA Resources Inc (Editor), Environmental Management for Mining, Saskatoon.

Kostof, S. (1991) The city shaped: urban patterns and meanings through history, Bulfinch Press, New York, 352 p.

MacMillan, R., Nikiforuk, W., Pawlina, M., Robertson, S., Turchenek, L. and Pettapiece, W. (2006) Identify, characterize \& quantify the types of landforms and landscape patterns present in the Regional Municipality of Wood Buffalo, Cumulative Effects Management Association, Fort McMurray, Alberta.

McKenna, G. (2002) Sustainable mine reclamation and landscape engineering, PhD Thesis, Department of Civil and Environmental Engineering, Edmonton, Alberta, 660 p.

McKenna, G. (2009) Techniques for creating mining landforms with natural appearance, Proceedings of Tailings and Mine Waste '09. Banff, Alberta. November 1-4, 2009. The University of Alberta Geotechnical Centre.

Ontario Ministry of Northern Development and Mines (1996) Rehabilitation of mines: Guidelines for proponents, Version 1.1. Ontario Ministry of Northern Development and Mines, Sudbury, Ontario.

Pearman, G. (2009) 101 Things to Do with a Hole in the Ground, Published by Post-Mining Alliance in association with the Eden Project, Cornwall, UK, $132 \mathrm{p}$.

Russell, B., McKenna, G., Leblanc, M., Wells, P.S. and Anderson, B. (2010) Design and Construction of the Reclamation Surface for the First Oil Sands Tailings Pond. Proceedings Fifth International Conference on Mine Closure (Mine Closure 2010), A.B. Fourie, M. Tibbett and J. Wiertz (eds), 23-26 November 2010, Viña del Mar, Chile, Australian Centre for Geomechanics, Perth, pp. 563-574.

Schor, H.J. and Gray, D.H. (1995) Landform grading and slope evolution, Journal of Geotechnical Engineering, 121(10), pp. 729-734.

US Department of the Interior (1967) Surface mining and our environment: a special report to the nation, United States Department of the Interior, Washington, DC, $124 \mathrm{p}$. 